\title{
Effects of Investments Appraisal Methods on Shareholders Wealth for Companies Listed In Nairobi Security Exchange
}

\author{
John Muzee Barasa \\ Kenya Industria Research \& Development Institute (KIRDI) \\ P.O. BOX 30650, 00100 Nairobi, Kenya
}

\begin{abstract}
Investment decisions are essential for a business as they define the future survival, and growth of the organization. The main objective of a business being the maximization of shareholders' wealth, therefore a firm needs to invest in every project that is worth more than the costs.Morethanever,corporateexecutivesareunderincreasingpressuretodemonstrateonaregularbasisthattheyarecr eatingshareholdervalue.Thispressurehasledtoanemergenceofavarietyofmeasuresthatclaimtoquantifyvaluecreatin gperformance. The study examined the effectsofinvestmentappraisal methods onshareholderswealthforcompanieslistedinNairobiSecuritiesExchange. The study was guided by the following objectives: tooestablish the effectofassetallocation and markettiming appraisal methodsontheshareholderswealthforthecompanieslistedintheNairobiSecuritiesExchange.Target population was for Top Management and Middle level Management. Thesample sizeofthisstudy composed ofthetop Level ManagementandtheMiddle level Management ofthe57firmslistedintheNairobisecuritiesexchange. The research used a correlation study in nature, The sampling techniques used in the study was stratified simple random sampling the data collected used both primary and secondary data and before the questionnaire was administered it underwent pilot testing.

Dataweretabulatedandanalyzedusingcorrelationmodelsinordertodeterminehowtheinvestmentappraisal methods were correlatedwiththeshareholderswealth.Afterobtainingtherelevantstatistics, dataweretabulatedand the results interpretation,conclusion,recommendations made.Pilot testing of the data collection tools was done.it helped identify weaknesses in the data collections tools piloting was done using 10 respondent randomly selected from the 57 firms listed in the Nairobi Security Exchange. Theinstrumentsthat wereusedinthisstudyweremajorlysecondarydata and semi-structuredquestionnaires. The findings of the study indicated that there was a positive relationship between asset allocation and shareholders wealth in the years between the years 2009 to 2013. There was a positive relationship between market timing in stock and shareholders wealth in the years between years 2009 to 2013 in Nairobi securities exchange. The findings of the study indicated that asset allocation and market timing investment methodpositively influenced shareholder wealth positively when other factors were kept constant. There should be a study replicated in other sectors of the companies not listed in the Nairobi Securities Exchange and also similar research can be done for other stock exchange in other countries
\end{abstract}

\section{Background of the Study}

Investment decisions are essential for a business as they define the future survival, and growth of the organization. The main objective of a business being the maximization of shareholders' wealth, Therefore a firm needs to invest in every project that is worth more than the costs. Whichinvestmentmethodsarebest?Financialanalysts,moneymanagers,andfinancialmediahavealwaysarguedaboutt hisquestionandstilltheycontinuetoargue.Sowhatisthebestsolution?Manyindividualssimplychoosetobelievesomeon ethey'veheardontelevision,ormaybesomeonetheircompanysuggested.Theyalsofamouslytendtochangetheirmindev eryfewyearsastowhatisthebestinvestmentchoice, likelybecauseithasperformedwellinthemostrecentshortperiodofti me.Armittage, Howard \& Kaplan (1994)

Capitalmarketsarebecomingincreasinglyglobal.Investorscanreadilyshiftinvestmentstohigheryielding,oft enforeign,opportunities.Corporategovernanceisshifting, withownersnowdemandingaccountabilityfromcorporatee xecutives.Manifestationsoftheincreasedassertivenessofshareholdersincludethenecessityforexecutivestojustifythei rcompensationlevels, andwell-publicizedlistsofunderperformingcompaniesandoverpaidexecutives (David, 2004). The heightened aversion towards global equities and the subsequent sell-off in both the developed and frontier markets in Sub-Saharan Africa including Kenya are likely to continue, this means that foreign investors may remain cautious hence reduced activity at the local, bourse until the shilling shows signs of stability and the high inflation rate start receding.

David Achungo, at investment manager at Pine Bridge Investments limited indicated that stock market analysis at the beginning of August 2013 revealed that more than Sh20 billion worth of investor's wealth was 
wiped off at the Nairobi Stock Exchange (NSE) during the first week of August as the bear run deepened and investors fled for safety in the bond market.

On the other hand, bonds trading more than doubled, from Sh4.5 billion to Sh9.9 billion with the total deals transacted in the week also increasing to 126 from 52 in the previous week. According to Standard Investment Bank (SIB) activity at the bourse remained equally split between foreign and local investors, with foreign investors remaining net sellers.

The NSE has experienced a net foreign investor outflow of Sh2 billion in the period January to August the year 2013, compared to net inflows of Sh8 billion in similar period last year 2012 . ProfitwarningsattheNairobiSecuritiesExchangeonFridayroseto10inaperformancethathasinvestorswhogotonlytwo suchalertslastyearlosebillionsofshillingsthroughsharepriceerosions.

MostofthesecompanieshaveseentheirmarketvaluedeclineattheNairobibourseoverthepastsixmonths.Durin gthesame period NairobiSecurities Exchange has seenthestockmarketgain by 23.3percent,aidedbytheperformanceofmostbluechipfirmsandincreasedforeigninvestorinterest.

Thehighprofitalertsthisyearhadbeendrivenbytheweaklocalandglobaleconomybesidesotheruniquefactorst hathaderodedearningsofindividualfirms.Investorsinthecompaniesthathadissuedprofitwarningsaresettogetloweror nodividendthisyear,besidessufferingsharepriceerosion (Duke, 1993).

Inthesameperiod,EAPCC'ssharepricedipped31.2percenttoSh42asKQ'ssharelost18.5percenttoSh12.2.Ot herfirmsthatrecordedsharepriceerosioninthesameperiodincludeEaagadsandKakuziwhosesharesdropped30.4and1 2.5percentrespectivelytoSh24.5andSh70apiece.

Investorsinothercompaniesthathavepostedstrongprofitgrowthhave,however,seentheirpaperwealthriseby doubledigits,highlightingthenegativeimpactoflossesandslowearningsoninvestorwealth. Safaricominvestorshadben efittedthemost, withthestock'spricerising 50.7percentoverthepastsixmonthstoSh4.9, withthecompanyreportinga98. 3percentgrowthinnetprofittoSh7.7billioninfirsthalfendedSeptember Buzzel (1996)

Fourmethodsofinvestment appraisal techniques areAssetAllocation,MarketTiming, Fundamental/TechnicalAnalysis and modern portfolio methods. Thisstudyassessedthe effects ofinvestmentappraisal methodsontheshareholderswealth for companies listed in Nairobi Securities Exchange.

\section{Statement of the Problem}

Despite the popularity of many investment methods, studies have revealed that the rate of change in shareholders wealth have stagnated due to in adequate application and use of appraisal methods of investment. Ryan \& Ryan (2002)

According to Darbar, (2010) statistics show that for the 20 years ending December 31, 2009Investors' annualized returns reflected negative trend such that the impact was not positively reflected in the competitive market: Equity $3.17 \%$, fixed income $1.02 \%$, and asset allocation $2.34 \%$, all returns are before an inflation correction of $2.80 \%$, Which leaves investors with 20 years real equity annualized return of $0 . .73 \%$ and negative annualized returns for fixed income of $-1.78 \%$ and asset allocation $-0.46 \%$

StudiesbyMichaelBarnet(2006)indicatedthatcontradictoryschoolsofthoughtexistabouthowtoconstructap ortfolioofequitiestomaximizeshareholderwealth. Modern Portfolio theory is the foundation of the mutual fund industry. It's widely promoted as the way investors should allocate capital to be in line with money management practices.

Moreover,alotofmarkettimingbyfinancialanalysts,manyinvestorsarestillosingvaluewhileothersaregainin gvalueintheirinvestments(StandardInvestmentBank,2012).

It's on this basis that there was need to carry out the research on the effects of investments appraisal methods on shareholders wealth for companies listed in Nairobi Securities Exchange

\section{Research Objectives}

Theoverallobjectiveof the study was to establish theeffectofinvestment appraisal methodsonshareholderswealthin NairobiSecuritiesExchange.

Thespecificobjectivesof the studywere:

i) Toestablish the effectofassetallocation on shareholderswealthforthecompanieslistedintheNairobi Securities Exchange.

ii) TofindouttheeffectofmarkettimingappraisalmethodsonshareholderswealthforthecompanieslistedintheNairobi SecuritiesExchange.

\section{Research Questions}

i) What are the effects of assetallocation onshareholderswealthfor companies listed intheNairobiSecuritiesExchange? 
ii) How does markettimingaffectshareholderswealthforthelistedcompaniesintheNairobiSecuritiesexchange?

\section{Justification}

This study was of great significance to the top management in planning; executing and balancing the resource of a company in a way that there is maximum work output to attain the goals of the company, while retaining the work quality by ensuring shareholders wealth were created. Shareholders are owners of the companies.

They play an important role in the financing, operating, governance and control aspects of a company, shareholders expects value from their investment, employees; the main objectives of a business owners is profitability. Organizations success depends on the employees' performance through the expertise of human resource leader and the support of your company's executive leadership and in return employees derive their livelihood from the firm.

Scholars need to provide major gains in knowledge and gap for further research. The study will be of great importance to the government of Kenya and Policy-makers as it will provide information on aspects of investments appraisal methods on shareholders wealth for firms listed in NSE. In addition it will also provide information to understand the needs and problems of the study and solutions suggested to the problem

\section{Scope}

The study focused on the effects of investment appraisal methods on shareholders wealth for companies listed in Nairobi Securities Exchange, the information or data were obtained from top level management and middle level management. Theresearchcoveredfivefinancialyearsandconductedforallthe 57listedcompaniesintheNairobiSecuritiesExchange.

\section{Limitations}

ManyoftherespondentswerethetopexecutivesandmiddlelevelmanagementinthelistedfirmsinNairobiSecur itiesExchange.Mostofthetopexecutiveshadverybusyschedulesand were unable to findadequatetimetorespondtothequestionnaire.

Respondentsweregivenadequatetimetorespondwithvariousremindersthroughtheirpersonalassistantsandsecretaries .Further, thestudyhad established anetworkoffriendstothetopexecutives and middle level management inordertogetthequestionnairefilled.

\section{Literature Review}

Thischapter presents a review of literature related to investment appraisal methods andshareholderswealthof Nairobi Security Exchange. The chapter begins with a theoretical review and theories related to asset allocation and market timing which is followed by conceptual framework a literature review of variables. Empirical review, critique of the existing literature, summary and research gap

\subsection{Theoretical Review}

According to Kombo \& Tromp (2006) theoretical framework is a collection of interrelated ideas on theories. It is a reasoned set of prepositions which are derived from and supported by data or evidence, and also Kothari (2004). Stated that theoretical framework is simply a theory, but it can also be general as a basic approach to understanding the issues at hand.

\subsection{Asset Allocation}

The Dow Theory

Dow Theory comes from Charles Dow, who was a journalist and co-founder of Dow Jones and Company. He had several major beliefs in his Dow Theory. Markets have 3 trends: Most of the time, the market would move sharply in one direction, recedes briefly in another, and then resumes the original direction. This is the basis of most of technical analysis. Markets have 3 phases: accumulation by astute investors, then trend followers jump on board,

And finally the same astute investors begin unloading their shares.The stock market is relatively efficient: Stock prices react quickly to news.Stock market averages should confirm each other: When market indices begin to diverge, it typically signifies a change in direction its occurring trades are confirmed with volume.Trends exist, until real signals indicate otherwise.

\section{Elliot Wave Theory}

Developed by Ralph Elliot in the 1920's, Elliot Wave Theory suggests that the market moves in repetitive patterns called waves. The theory consists of the following; every market action is followed by a 
reaction, there are 5 waves in the direction of the main trend followed by 3 corrective waves. The cycle is over after the waves of 5 and 3. The 5-3 move becomes 2 subdivisions of the next higher 5-3 wave.

\subsection{Market Timing Theories}

MarketTimingisthestrategyofmakingbuyorselldecisionsoffinancialassets(oftenstocks)byattemptingtopre dictfuturemarketpricemovements. Thepredictionmaybebasedonanoutlookofmarketoreconomicconditionsresulting fromtechnicalorfundamentalanalysis. Thisisaninvestment strategybasedontheoutlookforanaggregatemarket,ratherthanforaparticularfinancialasset.

\section{MovingAverages}

Markettimingoftenlooksatvariousmovingaverages.Populararethe50-and200-

daymovingaverages. Somepeoplebelievethatifthemarkethasgoneabovethe50-or200dayaveragethatshouldbeconsideredbullish,orbelowconverselybearish.Mark

Technicalanalystsconsideritsignificantwhenonemovingaveragecrossesoveranother.Themarkettimersthenpredictth atthetrendwill,morelikelythannot,continueinthefuture.

Otherssay,"Nobodyknows"andthatworldeconomiesandstockmarketsareofsuchcomplexitythatmarkettimingstrateg iesareunlikelytobemoreprofitablethanbuy-and-holdstrategies.

Movingaveragestrategiesaresimpletounderstand, andoftenclaimtogivegoodreturns, buttheresultsmaybeconfusedby hindsightanddataminingValeriy\&Zakamulin (2013).

\section{DifferingViewsontheViabilityofMarketTiming}

Whocanpredictthenexteventsthatmayaffecttheeconomyandstockpricesseethemanyunforeseeable, unpredi ctable,uncertaineventsbetween 1985to2013,ofMeasuringEconomicPolicyUncertainty Report areshowninFigures1 to6pages37to42.FewpeopleintheworldcorrectlypredictedthetimingandcausesoftheGreat Recessionduring2007-2009.

Whethermarkettimingiseveraviableinvestmentstrategyiscontroversial.Somemayconsidermarkettimingto beaformofgamblingbasedonpurechance, becausetheydonotbelieveinundervaluedorovervaluedmarkets. Theefficien t-market hypothesisclaimsthatfinancialpricesalwaysexhibitrandom walkbehaviorandthuscannotbepredictedwithconsistency.

Someconsidermarkettimingtobesensibleincertainsituations, suchasanapparentbubble.However,becauseth eeconomyisacomplex

systemthatcontainsmanyfactors, evenattimesofsignificantmarketoptimismorpessimism, itremainsdifficult, ifnotimp ossible,topredeterminethelocal maximum or minimumoffuturepriceswithanyprecision;asocalledbubblecanlastformanyyearsbeforepricescollapse.Likewise,acrashcanpersistforextendedperiods;stocksthata ppeartobecheapataglancecanoftenbecomemuchcheaperafterwards, beforetheneitherreboundingatsometimeinthefu tureorheadingtowardbankruptcy.

Proponentsofmarkettimingcounterthatmarkettimingisjustanothernamefortrading. Theyarguethat"attemptingtopre dictfuturemarketpricemovements"iswhatalltradersdo,regardlessofwhethertheytradeindividualstocksorcollections ofstocks,aka,mutual funds.Thusifmarkettimingisnotaviableinvestmentstrategy,theproponentssay,and thenneitherisanyofthetradingonthevariousstockexchanges. Thosewhodisagreewiththisviewusuallyadvocateabuyand-holdstrategywithperiodicre-balancing.

\section{BrokeragesMayFavorInstitutionalInvestorsattheExpenseofSmallerRetailInvestors}

Perhapsconsistentwiththesetwoopposingviewsisthat,aswithanytypeoftrading,markettimingisdifficulttoc arryoutoaconsistentbasis, particularlyfortheindividualinvestors, unschooledintechnicalanalysis.Retailbrokersareals ogenerallyunschooledinboththemindsetandthetoolsneededtosuccessfullytimethemarket,andindeedmostareactivel ydiscouragedbythebrokeragesthemselvesfrommovingtheirclientsinandoutofthemarket.

However,asmarketmakers,manyofthesesamebrokeragestaketheoppositeapproachwiththeirlargeinstitutio nalclients,tradingvariousfinancialinstrumentsfortheseclientsinanattemptto"predictfuturemarketpricemovements" andtherebymakeaprofitfortheinstitutions, thisdichotomyinthetreatmentofinstitutionalvs.retailclientscanpotentially becontroversialforthebrokerages.

Itmaysuggestforexamplethatretailbrokersandtheirclientsarediscouragedfrommarkettiming,notbecauseitd oesn'twork, butbecauseitwouldinterferewiththebrokerages'marketmakertradingfortheirinstitutionalclients.

Inotherwords,retailclientsareencouragedtobuy and holdsoastomaintainmarket liquidityfortheinstitutionaltrading. Iftrue, thiswouldsuggestaconflictofinterest,inwhichthebrokeragesarewillingtosacrificepotentialreturnsforthesmall erretailclientsinordertobenefitlargerinstitutionalclients.

The2008declineinthemarketsisinstructive. Whilemanyretailbrokerswereinstructedbytheirbrokeragestotelltheirclie ntsnottosell,butinstead"looktothelongterm", 
Themarketmakersatthosesamebrokerageswerebusysellingtocashtoavoidlossesforthebrokerages'largeinstitutionalc lients. Theresultwasthattheretailclientswereleftwithhugelosseswhiletheinstitutionsfledtothesafetyofshorttermbond sandmoneymarketfunds, therebyavoidingsimilarlosses. RegardingUniversity of Michigan Consumer Sentiment Index,ThompsonReutersannouncedon08July2013thatiswassuspendingitsearlyreleasepracticeaspartofanagreemen twiththeNewYorkAttorneyGeneral'soffice.

\section{CurveFittingandOver-Optimization}

Amajorstumblingblockformanymarkettimersisthephenomenonofcurve

fitting. Thismeansthatagivensetoftradingruleshasbeenover-optimizedtofittheparticulardata

setforwhichithasbeenback-tested.Unfortunately,ifthetradingrulesareover-

optimizedtheyoftenfailtoworkonfuturedata.

Markettimersattempttoavoidthesedifficultiesinanumberofways. Oneisbylookingforclustersofparametervalueswhic hworkparticularlywell.Anotherisusingout-of-

sampledata,whichostensiblyallowsthemarkettimertoseehowthesystemwillworkonunforeseendata.However,critics chargethatoncethestrategyhasbeenrevisedtoreflectsuchdataitisnolonger"out-of-sample".

\section{IndependentReviewofMarket-TimingServices}

Severalindependentorganizations(for

instancesTimerDigestandHulbertFinancialDigest)havetrackedsomemarkettimers'performanceforoverthirtyyears. Theseorganizationshavefoundthatpurportedmarkettimersinmanycasesdobetterthanchance, orevenworse.

However, thereareexceptions, withsomemarkettimersoverthethirty-

yearperiodhavingperformancesthatsubstantiallyandreliablyexceedthoseofthegeneralstockmarketorthesectorsinwh ichthemarkettimersinvest.Jim

Simons'RenaissanceTechnologiesMedallionHedgeFundhasconsistentlyoutperformedthemarket.Thefundallegedly usesmathematicalmodelsdevelopedbyElwynBerlekamp.

Arecentstudysuggestedthatthebestpredictorofafund'sconsistentoutperformanceofthemarketwaslowexpensesandlo wturnover,notpursuitofavalueorcontrarianstrategy.However,otherstudieshaveconcludedthatsomesimplestrategies willoutperformtheoverallmarket.Onemarket-timingstrategyisreferredtoasTimeZoneArbitrage.

\subsection{EvidenceforMarketTiming}

MutualfundflowsarepublishedbyorganizationssuchasInvestment

InstituteandTrimTabs. Theseshowthatflowsgenerallytracktheoveralllevelofthemarket:investorsbuystockswhenpri cesarehigh,andsellstockswhenpricesarelow.Forexample,inthebeginningofthe2000sdecade, thelargestinflowstosto ckmutualfundswereinearly2000

Whilethelargestoutflowswereinmid-

2002,Itisgoodtonotethatthesemutualfundflowswerenearthestartofasignificantbear(down

trending)marketandbull(up

trending)marketrespectively.Asimilarpatternisrepeatedneartheendofthedecade.Thismutualfundflowdataseemstoi ndicatethatmostinvestors(despitewhattheymaysay)actuallyfollowabuyhigh,sellowstrategy.

Studiesconfirmedthatthegeneraltendencyofinvestorsistobuyafterastockormutualfundpricehasincreased.Thissurgei nthenumberofbuyersmaythendrivethepriceevenhigher.However,eventually, thesupplyofbuyersbecomesexhausted ,andthedemandforthestockdeclinesandthestockorfundpricealsodeclines. Afterinflows, theremaybeashort-

termboostinreturn,butthesignificantresultisthatthereturnoveralongertimeisdisappointing

Researcherssuggestthat,afterperiodsofhigherreturns, individualinvestorsselltheirvaluestocksandbuygrowthstocks. FrazziniandLamont(1996)

findthat,ingeneral,growthstockshavealowerreturn,butgrowthstockswithhighinflowshaveamuchworsereturn.

Darbar(2010)

studyfoundthattheaverageinvestor'sreturninstocksismuchlessthantheamountthatwouldhavebeenobtainedbysimply holdinganindexfundconsistingofallstockscontainedintheS\&P 500index.

Arecentstudysuggeststhatcorporationsandinvestmentbankscannottimethecreditmarkets.

TheyshowthatinvestmentbankssuchasGoldmanSachsdoaspoorlyasfirmslikeFordwhenitcomestotimingtheissuanc eoftheirbonds.

\section{Legality}

Whilemarkettimingislegal,theFinancial Industry

Regulatory

Authorityhaslongfrownedonthepracticesinceitpassesthetradingcoststolongterminvestors.Consequently,manybrokerageswillnotfillmarket-timingorders.

\section{WhatSomeFinancialAdvisorsSay}


Financial

advisorsoftenagreethatinvestorshavepoortiming,becominglessrisk aversewhenmarketsarehighandmoreriskaversewhenmarketsarelow. Thisisconsistentwithrecencybiasandseemscon trarytotheacrophobiaexplanation."Theonlyproblemisthat,unlikeMr.SpockofStar

Trekfame,humansarenotentirelyrationalbeings.

Proponentsoftheefficient-market

hypothesisclaimthatpricesreflectallavailableinformation.EMHassumesthatinvestorsarehighlyintelligentandperfec tlyrational.However,othersdisputethisassumption. "Ofcourse,weknowstocksdon'tworkthatway."Inparticular,prop onentsofbehavioral financeclaimthatinvestorsareirrationalbuttheirbiasesareconsistentandpredictable.

According to KennethR.French,G.WilliamSchwertandRobertF.Stambaugh(1987) anunexpectedincreaseinvolatilitylowerscurrentstockprices.

Total(TFP)GrowthVolatilityisnegativelyassociatedwiththevalueofU.S.corporations.Anincreaseof1\%inthestandar ddeviationoftotalfactorproductivity(TFP)growthisassociatedwithareductioninthevalue-

outputratioof $12 \%$.Changesinuncertaintycanexplainbusinesscyclefluctuations,stockprices, andbankingcrises.

\section{Conceptual Framework}

This study sought to establish the effects of investment appraisal methods on the shareholders wealth the independent variables were asset allocation and market timing investment appraisal methods

\section{Independentvariables}

Dependentvariable

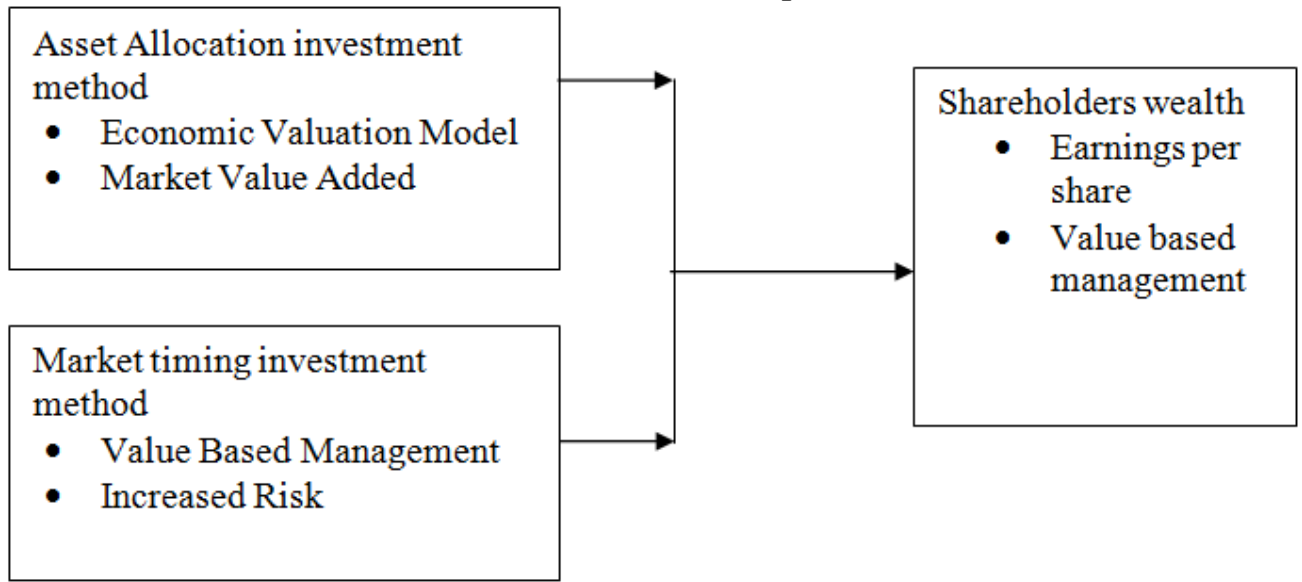

\section{Asset Allocation}

AccordingtoSamuelGichohi,aSeniorResearchAnalystatNICSecurities:Assetallocationreferstotheportion ingofaportfolioamongvarioustypesofinvestmentassetclassessoastomaximizereturnforagivenlevelofrisk, Justasitisprudenttodiversifyaportfolioamonganumberofholdingstoreducevolatility.

Itisalsogenerallyrecommendedthataninvestorspreadouthisorherinvestmentsamongseveralassetclasses.Becausedif ferentcategoriesforexample,domesticbondsandforeignstocksmighthavereturnsthatarenotcloselycorrelated,investi nginbothcanhelpprovidedownsideprotectionshouldoneortheotherbegintodecline.

Withinequities(stocks), therearemanysub-categories, basedoncompanysize(market capitalization),industry(retail,technology, healthcare others), style(growth, value, income), andlocation(domesticorforeign).Likewise, thefixed-

among incomecategorycanbebrokendownbymaturity,credit quality,andissuer(corporation,municipality,government and others).

Therearealsomanyalternativeinvestmentstoconsider,suchasreal

estate, derivatives,preciousmetals, andcollectibles.Assetallocationisatermusedtodescribehowaninvestorchoosestod ivideuphisorherinvestmentsmethod.

\footnotetext{
Market Timing

Markettimingisthestrategyofmakingbuyorselldecisionsoffinancialassets(oftenstocks)byattemptingtopredictfutur emarketpricemovements. Thepredictionmaybebasedonanoutlookofmarketoreconomicconditionsresultingfromtec hnicalorfundamentalanalysis. Thisisaninvestment strategybasedontheoutlookforanaggregatemarket,ratherthanforaparticularfinancialasset.

Markettimingoftenlooksatvariousmoving averages.Populararethe 50 -and 200 daymovingaverages. Somepeoplebelievethatifthemarkethasgoneabovethe50-or200dayaveragethatshouldbeconsideredbullish, orbelowconverselybearish.Technicalanalystsconsideritsignificantwhe nonemovingaveragecrossesoveranother.
} 
Themarkettimersthenpredictthatthetrendwill,morelikelythannot,continueinthefuture.Otherssay,"Nobodyknows"a ndthatworldeconomiesandstockmarketsareofsuchcomplexitythatmarkettimingstrategiesareunlikelytobemoreprofi tablethanbuy-and-

holdstrategies.Movingaveragestrategiesaresimpletounderstand, andoftenclaimtogivegoodreturns, buttheresultsma ybeconfusedbyhindsightanddatamining.

\section{Shareholders wealth}

According to Ehrbar (1998) Maximizing shareholders wealth has become the new corporate paradigm. Managers and researchers have traditionally recognized shareholders wealth maximization as the ultimate corporate goal. The owner of the company that is the shareholders wealth means maximizing the net worth of the shares held by them.

Therefore wealth maximization means creation of maximum value for company's shareholders which is a long term proposition that delivers higher economic output and through productivity gains, employment growth and higher wages. Management most important mission is to maximize shareholders wealth

According to Reid (2007) shareholders or stockholders own parts or shares of companies. In large corporations, shareholders are people and institutions that simply invest money for future dividend and for the potential increased value of their shares whereas in small companies.

They may be the people who established the business or have a more personal stake in it. In terms of poor performance in generation of shareholders wealth, the most preferred response will be top management replacement, followed by divided omission and employee layoffs in that order .

\section{Summary}

This chapter has captured theoretical and empirical literature on the effectsofinvestmentappraisal methods onshareholderswealthforcompanieslistedinNairobiSecuritiesExchange. A lot of studies have been carried out in the developed world with limited cases of study in the developing world. The contribution of investmentappraisal methods onshareholderswealthcannot be ignored.

\section{Research gap}

According to Reid (2007) shareholders or stockholders own parts or shares of companies. In large corporations, shareholders are people and institutions that simply invest money for future dividend and for the potential increased value of their shares whereas in small companies. This study did not cover the effectofassetallocation,markettiming appraisal investment methodsontheshareholderswealthforthecompanies notlistedintheNairobiSecuritiesExchange.

\section{Researchmethodology}

outlines the procedures and methods the researcher employed in carrying out the study, the section comprised of the research design,targetpopulation,samplingsize and sample techniques, datacollectionanddataanalysismethods.

A research design is the structure, or the blueprint, of research that guides the process of research from the formulation of the research questions and hypotheses according to Kothari (2010) a research design is a master plan that specifies the methods and procedures for collecting and analyzing the needed information. According to Johnson (2002) research design provides a framework or plan of action for the research objectives of the study. Whichwere determined during the early stages of the research and were included

The researcher determined the sources of information and the design technique. This study used a correlation research design to identify the relationship between the independent variables and the shareholders wealth the dependent variable

Lavrakas (2008) described a correlation research as a type of descriptive non-experimental research because it described and assesses the magnitude and degree of an existed relationship between two or more continuous quantitative variables with interval or ratio types of measurements or discrete variables with ordinal or nominal type of measurements.

According to Kothari (2004) a sample of $30 \%$ is recommended for a representative of thetargetpopulationforthetop level management and middle level management was 456 ofallthe57firmslistedintheNairobistockexchange.

Table 3.1: Target Population

\begin{tabular}{lcc}
\hline Category & Target Population & 30\% Sample size \\
\hline Top level management & 114 & 34 \\
Middle level management & 342 & 102 \\
\hline Total & $\mathbf{4 5 6}$ & $\mathbf{1 3 6}$ \\
\hline
\end{tabular}




\section{Sample Size and Sampling Technique}

Lavrakas (2008) describes a sample in a survey research context as a subset of elements drawn from a larger population. Kothari (2004) describe a sample as a collection of units chosen from the universe to represent it.

Gerstman (2003) stated that a sample was needed because a study that is insufficiently precise or lacks the power to answer research questions is a waste of time and money. A study that collects too much data is also wasteful. Therefore, before data was collected, it was essential to determine the sample size requirements of the study.

Beck and Polit(2003) clearly stated that it is more practical and less costly to collect data from a sample than from an entire population. Various methods of obtaining samples were available. These methods vary in cost, effort, and skills required, but their adequacy was assessed by the representativeness of the selected sample.

Johnson (2002) stated that properly taken samples enable an accurate portrayal of the research population while avoiding the prohibitive costs of surveying everyone. This study used stratified random sampling. Stratified random sampling used in each firmto form two strata's.

The strata of senior management and middle level management each of the two strata simple random sampling was done to identify individual respondents who were issued with a questionnaire to respond to the research statements. The sample size was 34 top level management and 102 middle level management resulting to 136 respondents

\section{Instruments}

Thestudyusedbothprimarydataaswellassecondarydata. Primary data according to Mugenda \& Mugenda (2003) is the data collected directly from first-hand experience which have not been subjected to processing or any other manipulation. Inthisregard,secondary datawillbeanalyzedandevaluatedfromthepublishedfinancialstatements.Further,questionnairesusedtoindependentl ygetresponsesontheeffectofvariousinvestmentappraisal

methodsonshareholderswealth. Thequestionnairesusedweresemi-

structured.Thequestionnairehadbothclosedquestionsandafewopenendedquestions.

\section{Data Collection Procedure}

The study sought an introductory letter from Jomo Kenyatta University of Agriculture and Technology. This was used to get a permit from National Commission for Science Technology and Innovation (NACOSTI). This was then presented to the listed firms of Nairobi Securities Exchange authorized the study. The data's were scheduled to administer questionnaires to top level management and middle level management.

\section{Pilot Test}

Pilot testing of the data collection tools was done. It was important since it helped identify weaknesses in the data collection tools the piloting was done using 10 respondents randomly selected from the 57 firms listed in Nairobi Security Exchange the 10 were not included in the actual study. This was beforethequestionnairewas administered it had to undergopilottesting thiswastorevealwhetherthetargetpopulationwasabletocomprehendandgiveinformationneeded.Thequestionnaires weredistributedtotherespondentsdirectlyandcollectedlater.

Validity is a measure of the degree to which data obtained from the instruments accurately and meaningfully represents the theoretical concept and in particular how the data represents the variables Kothari (2004). Validity was tested through discussions with the supervisor and colleagues' that had done masters. The advice guided the researcher to revise the instrument accordingly.

Reliability is the measure of the degree to which a research instruments yields consistently the same results after a repeated trials Mugenda \& Mugenda (2003) tests- retest technique was done to test reliability of the instruments. It involved administering the same instrument twice within two weeks. Cronbach Alpha coefficient was used to test reliability. A coefficient of more than 0.7 indicated that the instrument was reliable.

\section{Data Processing and Analysis}

The data analysis is the process of simplifying data in order to make it comprehensive Frankel $\&$ Wallen (2000) the study adopted both qualitative and quantitative analysis. This was because the data being analyzed was both numerical and textual. 
The data was checked for accuracy, completeness of recording errors and omission. The data that was obtained from the questionnaires were primarily qualitative and were analyzed using multiple linear regressions to identify the level of statistical significant of independent variables on the dependent variable.

According to IBM (2010) multiple linear regressions is useful in situations where there are more than two independent variables and the dependent variable is categorical. Data was tabulated using software program for social sciences (SPSS version 20) to develop charts that allowed easy interpretation, conclusion and recommendation.

The instrument that was used in the study was majorly secondary data and questionnaires. T-test was used to test the significance of the overall model at a 10 percent confidence level as shown below.

$\mathrm{Y}=\beta_{0}+\beta_{1} \mathrm{x}_{1}+\beta_{2} \mathrm{x}_{2}+\mathrm{e}$

$\beta_{0}=$ constant

$\beta_{1}=$ asset allocation investment

$\beta_{2}=$ market timing

\section{Research Findings And Discussion}

The study sought to find out theeffectsofinvestment appraisal methods ontheshareholderswealthforcompanies listed inNairobiSecuritiesExchange. This chapter endeavored to present, discuss and interpret the findings of the study. The findings were presented according to the research objectives that were formulated in Chapter One. Questionnaires were used for collecting data from the respondents.

The collected data was sorted so as to remove the incomplete questionnaires and to facilitate coding. Quantitative data was then keyed into SPSS version 20 for analysis while qualitative data was put into theme categories that presented the situation as reported by the respondents. Both quantitative and qualitative were analyzed and presented by use of frequencies and percentages, through tables and figures.

\section{Response Rate}

The researcher issued 57 questionnaires to the respondents and 51 were well filled and returned. This represented an $89.5 \%$ response rate. According to Babbie (1990), a response rate of $60 \%$ is good, $70 \%$ very good and 50\% adequate for analysis and reporting from manual surveys. Bailey (1996) sets the adequacy bar at $75 \%$ and Chen (1996) argues that the larger the response rate, the smaller the non-response error.

\section{Background Information of the Respondents}

The study sought to find the background information of the respondents. Although it was not part of the purpose of the study, this set of data was intended to describe demographic variables of the sample and to assess for any influence on the research findings.

\section{Gender of the respondents}

The study sought to find out the gender of the respondents. The findings were presented in Figure 4.1. From the figure $66.7 \%$ of the respondents were male while $33.3 \%$ were female. Therefore, the findings of this study can be generalized to either or both genders as there was adequate representation from each.

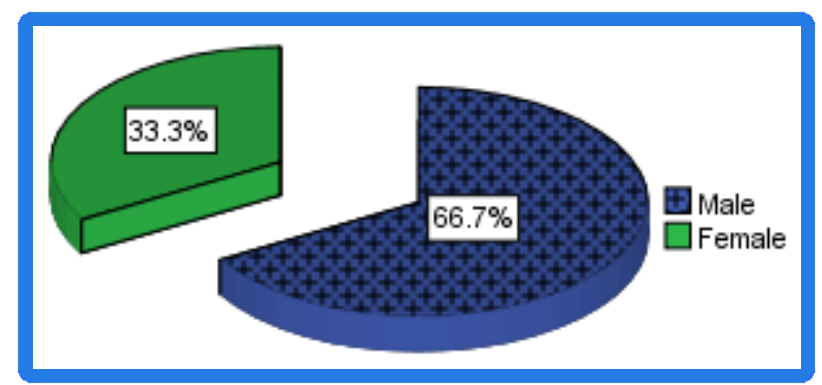

Figure 1: Gender of the respondents

\section{Role the respondents play in the investments in their companies}

The research sought to establish roles that respondents play in the investments in their respective companies. The findings were summarised in Figure 4.2, from which a majority were either Finance Managers Specialist or Investment Specialist, each with $41.2 \%$. Top Management was represented by $17.6 \%$ of the respondents. Therefore, the data collected is rich in information as opinions of the most relevant people in the study were sought. 


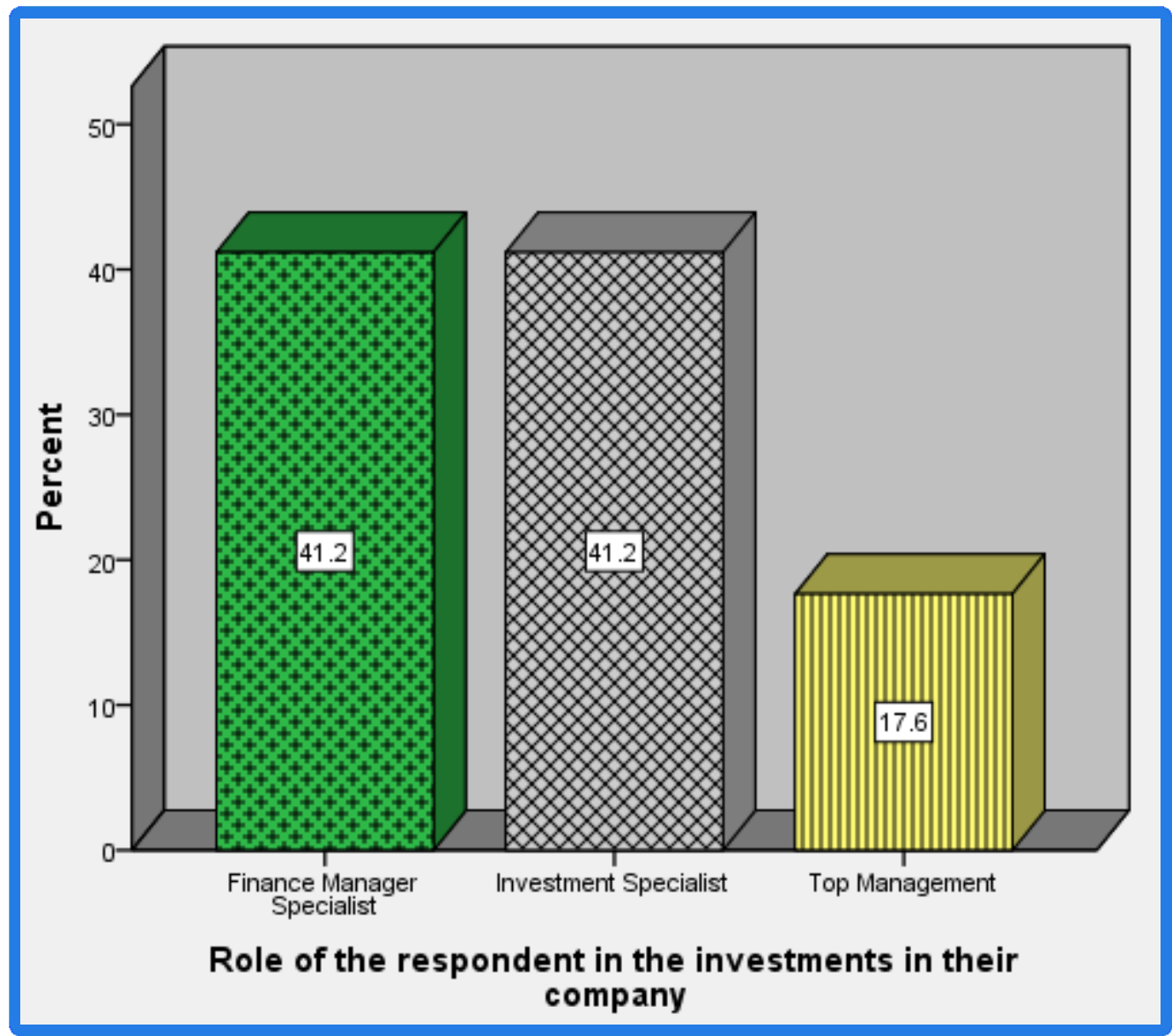

2: Roles played by the respondents in the investments in the companies Years of experience of the respondents

The study went out to find the experience in terms of years that respondents had in investments. The findings were tabulated in Table 4.1. From the table, a majority $(51.0 \%)$ of the respondents had 5-10 years of experience, $31.4 \%$ had more than 10 years in experience and $17.6 \%$ had less than 5 years in investment experience. Since the majority of the respondents had over 5 years of experience, then the data collected could be said to be very relevant to the concepts sought through the questionnaire.

Table 1: Respondent's years of experience in investment

\begin{tabular}{lccc}
\hline Experience & Frequency & Percent & Cumulative Percent \\
\hline Below 5 years & 9 & 17.6 & 17.6 \\
5-10 years & 26 & 51.0 & 68.6 \\
above 10 years & 16 & 31.4 & 100.0 \\
Total & $\mathbf{5 1}$ & $\mathbf{1 0 0 . 0}$ & \\
\hline
\end{tabular}

Determining the Effect of Asset Allocation on Shareholder Wealth for the Companies Listed in the Nairobi Securities Exchange

The research

sought

to

determine

theeffectofassetallocation

onshareholderswealthforthecompanieslistedintheNairobiSecuritiesExchange. The findings were summarized and discussed under this section.

\section{Undertaking of investmentinstocks \\ assetallocationinvestmentmethodsinordertobuildshareholderswealth}

as

an

The study sought to establish if the companies undertook an investment in stocks as an asset allocation method in order to build shareholders wealth. The findings were presented in Figure 4.3. The figure shows that a bigger majority (94.1\%) of the respondents said that their companies undertook investments in stocks as an asset allocation investment method, while only $5.9 \%$ said that their companies did not. 


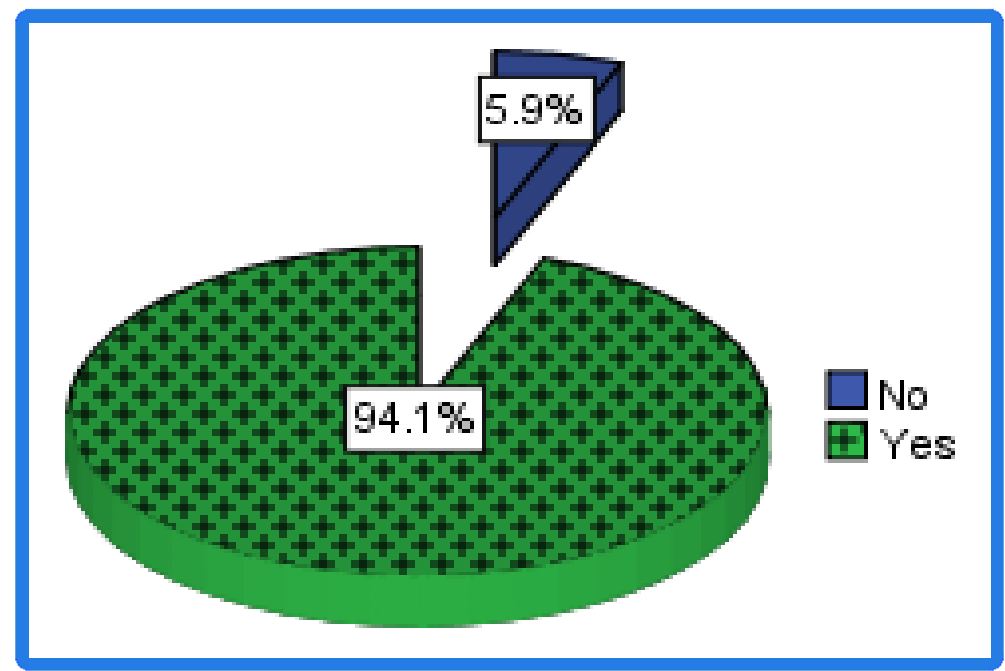

Figure 3: Undertaking of investment in stocks in order to build shareholders wealth

2 Undertaking of investmentin bonds as an assetallocation investment methodsinordertobuildshareholderswealth

The study sought to find out whether the companies undertook an investment in bonds as an asset allocation method in order to build shareholders wealth. The findings were presented in Figure 4.4. From the figure, a majority $(88.2 \%)$ of the respondents said that their companies undertook investments in bonds as an asset allocation investment method, while only $11.8 \%$ said that their companies did not.

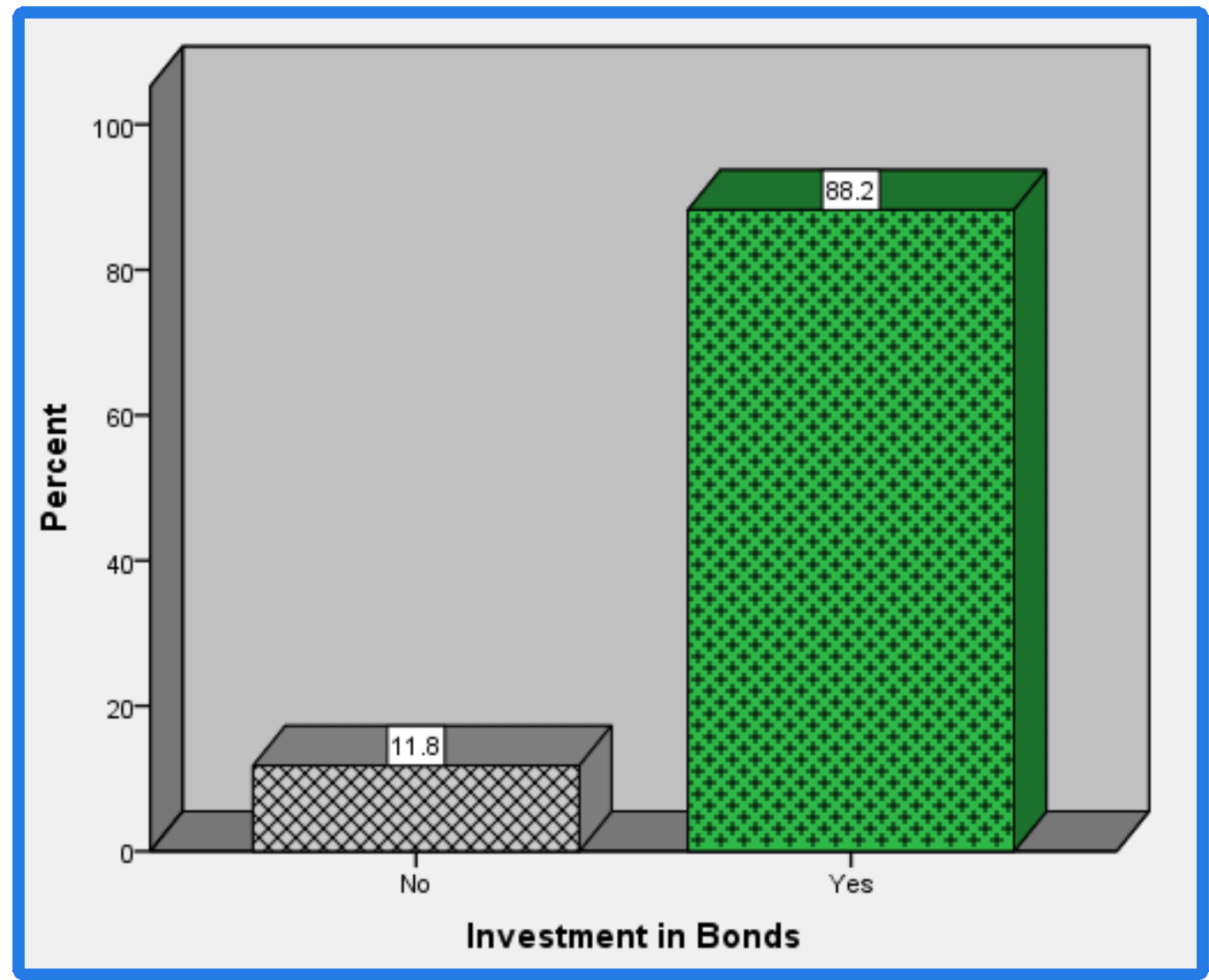

Figure 4: Undertaking of investment in bonds in order to build shareholders wealth

\section{Effects oftheassetallocationinvestmentmethodsonshareholderswealth}

The study sought to establish the effects that asset allocation investment methods had on shareholders wealth. The findings were summarized in Table 4.2 . The table shows that $80.4 \%$ of the respondents said that 
InvestmentinStocks increases shareholders wealth while $19.6 \%$ said it decreases. $90.2 \%$ said OffshoreInvestments increases shareholders wealth while $9.8 \%$ said it decreases. $60.8 \%$ said investmentinamodernPortfolio increases shareholders wealth while $39.2 \%$ said it decreases. $54.9 \%$ said InvestmentinBonds increases shareholders wealth while $45.1 \%$ said it decreases.

Table 2: Effects of the asset allocation investment methods on shareholders wealth

\begin{tabular}{|c|c|c|c|c|}
\hline \multirow{2}{*}{$\begin{array}{l}\text { Assetallocationinvestment } \\
\text { methods }\end{array}$} & \multicolumn{2}{|c|}{ Decrease } & \multicolumn{2}{|c|}{ Increase } \\
\hline & $\mathbf{F}$ & $\%$ & $\mathbf{F}$ & $\%$ \\
\hline Investmentinstocks & 10 & 19.6 & 41 & 80.4 \\
\hline OffshoreInvestments & 5 & 9.8 & 46 & 90.2 \\
\hline
\end{tabular}

\section{Investment theories in stock and how they affect shareholders wealth}

The study sought to establish ways in which investment theories in stock affect shareholders wealth. The findings of the study were tabulated in Table 3. From the table, 52.9\% of the respondents agreed that there had beenapositiverelationshipbetweeninvestmentsinstockandshareholderswealthin the lastfiveyears. A simple majority $\quad(58.8 \%) \quad$ strongly thagreed there had beenanegativerelationshipbetweeninvestmentsinstockandshareholderswealthforthelastfiveyears. Further, 58.8\% of the respondents agreed that offshoreinvestmentshad hadaneffectonshareholderswealthinNSE.

Table 4Ways in which investment theories in stock affect shareholders wealth

\begin{tabular}{|c|c|c|c|c|c|c|c|c|c|c|c|}
\hline \multirow[t]{2}{*}{ Statements } & \multicolumn{2}{|c|}{$\begin{array}{l}\text { Strongly } \\
\text { disagree }\end{array}$} & \multicolumn{2}{|c|}{ Disagree } & \multicolumn{2}{|c|}{ Neutral } & \multicolumn{2}{|c|}{ Agree } & \multicolumn{2}{|c|}{$\begin{array}{c}\text { Strongly } \\
\text { agree }\end{array}$} & \multirow[t]{2}{*}{$\begin{array}{l}\text { Total } \\
\%\end{array}$} \\
\hline & $\mathbf{F}$ & $\%$ & $\mathbf{F}$ & $\%$ & $\mathbf{F}$ & $\%$ & $\mathbf{F}$ & $\%$ & $\mathbf{F}$ & $\%$ & \\
\hline $\begin{array}{l}\text { There is a positive relationship between } \\
\text { investment in stock and shareholders } \\
\text { wealth in the last five years }\end{array}$ & 1 & 2.0 & 6 & 11.8 & 0 & 0 & 27 & 52.9 & 17 & 33.3 & 100.0 \\
\hline $\begin{array}{l}\text { There has been a negative relationship } \\
\text { between investment in stock and } \\
\text { shareholders wealth for the last five years }\end{array}$ & 30 & 58.8 & 13 & 25.5 & 0 & 0 & 8 & 15.7 & & & 100.0 \\
\hline $\begin{array}{l}\text { Offshore investments had had an effect on } \\
\text { shareholders wealth in NSE }\end{array}$ & 1 & 2.0 & 8 & 15.7 & 0 & 0 & 30 & 58.8 & 12 & 23.5 & 100.0 \\
\hline
\end{tabular}

Effect of Market Timing Method on Shareholders Wealth for the Companies Listed in the Nairobi Securities Exchange

The research sought to find out the effectofmarkettimingmethodonshareholderswealthforthecompanieslistedintheNairobiSecuritiesExchange. The findings were summarized and discussed under this section.

\section{Company undertaking of market timing tobuildshareholderswealth}

The study sought to find out if the companies undertook market timing to build shareholders wealth. The findings of the study were suammrised in Figure 4.5. From the figure, $72.5 \%$ of the respondents said that their companies undertakes market timing to build shareholders wealth while $27.5 \%$ of the respondents said that their companies did not.

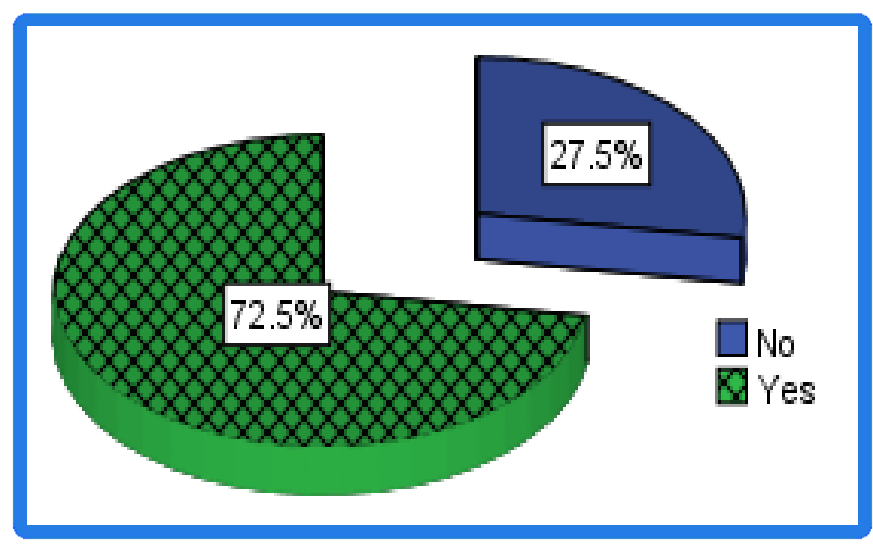

Figure 5: Company undertakes market timing to build shareholders wealth 


\section{Effectofmarkettimingand shareholders wealth}

The research sought to establish the effect that market timing had on shareholders wealth. The findings were summarized in Table 4.4. From the findings, $45.1 \%$ of the respondents agreed that there had beena positive relationshipbetweenmarkettimingandshareholderswealthinthelastfiveyears. A majority (51.0\%) disagreed that there had beenanegativerelationshipbetweenmarkettimingandshareholderswealthforthelastfiveyears. $\quad 51.0 \%$ strongly agreed that market timing investmentmethod had hadaneffectonshareholderswealthinNSE.

Table 4: Descriptive on effect of market timing and shareholders wealth

\begin{tabular}{|c|c|c|c|c|c|c|c|c|c|c|c|}
\hline \multirow[t]{2}{*}{ Statements } & \multicolumn{2}{|c|}{$\begin{array}{l}\text { Strongly } \\
\text { Disagree }\end{array}$} & \multicolumn{2}{|c|}{ Disagree } & \multicolumn{2}{|c|}{ Neutral } & \multicolumn{2}{|c|}{ Agree } & \multicolumn{2}{|c|}{$\begin{array}{c}\text { Strongly } \\
\text { agree }\end{array}$} & \multirow[t]{2}{*}{ Total \% } \\
\hline & $\mathbf{F}$ & $\%$ & $\mathbf{F}$ & $\%$ & $\mathbf{F}$ & $\%$ & $\mathbf{F}$ & $\%$ & $\mathbf{F}$ & $\%$ & \\
\hline $\begin{array}{l}\text { There has been } \\
\text { a positive relationship between } \\
\text { market timing and shareholders } \\
\text { wealth in the last five years }\end{array}$ & 2 & 3.9 & 7 & 13.7 & 0 & 0 & 23 & 45.1 & 19 & 37.3 & 100.0 \\
\hline $\begin{array}{l}\text { There has been a negative } \\
\text { relationship between market } \\
\text { timing and shareholders wealth } \\
\text { for the last five years }\end{array}$ & 19 & 37.3 & 26 & 51.0 & 0 & 0 & 6 & 11.8 & & & 100.0 \\
\hline $\begin{array}{l}\text { Market timing } \\
\text { Investment Method has an effect } \\
\text { on shareholders wealth in NSE }\end{array}$ & 1 & 2.0 & 3 & 5.9 & 0 & 0 & 21 & 41.2 & 26 & 51.0 & 100.0 \\
\hline
\end{tabular}

Multiple Linear Regression Analysis of Dependent Variable (Shareholders Wealth for the Companies Listed In NSE) and Independent Variables

Multiple linear regression analysis was done to find out the influence of independent variables (Asset allocation and Market timing method on the dependent variable (Shareholders wealth for the companies listed in NSE). Cooper and Schindler (2011) posit that regressions analysis shows the change in the dependent variable that can be explained by the independent variables. The findings of the study were tabulated and discussed under this section.

Beta regression coefficients were computed to indicate the magnitude or strength of effect of the independent variables on the dependent variable. The findings were summarized in Table 4.8. The tables shows that, for every unit change in Shareholders wealth for the companies listed in NSE, Asset allocation, Market timing method, Fundamental/Technical analysis investment method, and Modern portfolio investment method contributes .695, 1.356, 1.284 and -.046, respectively when all other factors are kept constant. Furthermore, the contributions are all statistically significant (p-value is less than .05).Hence the regression model is:

$\mathrm{SHW}=2.108+0.695 \mathrm{X}_{1}+1.356 \mathrm{X}_{2}$

Coefficients table of dependent variables (Shareholders wealth for the companies listed in NSE) and independent variables

Coefficients $^{\text {a }}$

\begin{tabular}{|c|c|c|c|c|c|}
\hline \multirow[t]{2}{*}{ Model } & \multicolumn{2}{|c|}{ Unstandardized Coefficients } & \multirow{2}{*}{$\begin{array}{c}\begin{array}{c}\text { Standardized } \\
\text { Coefficients }\end{array} \\
\text { Beta }\end{array}$} & \multirow[t]{2}{*}{$\mathbf{T}$} & \multirow[t]{2}{*}{ Sig. } \\
\hline & B & Std. Error & & & \\
\hline (Constant) & 2.108 & 2.393 & & .881 & .007 \\
\hline Asset allocation & .695 & .134 & .089 & .708 & .000 \\
\hline Market timing method & 1.356 & .185 & .230 & 1.928 & .006 \\
\hline
\end{tabular}

a. Dependent Variable: Shareholders wealth for the companies listed in NSE

Hence the resultant regression model is:

\section{Model summary of the dependent and independent variables}

From Table 4.9, 86.2\% (R Square $=.862$ ) of Shareholders wealth for the companies listed in NSEcould be explained by the independent variables Asset allocation, Market timing method, Fundamental/Technical analysis investment method, and Modern portfolio investment method, when other factors were kept constant. 
Effects of Investments Appraisal Methods on Shareholders Wealth for Companies Listed In ....

Table 5: Model Summary Table of Shareholders wealth for the companies listed in NSE and independent variables

\begin{tabular}{lcccc}
\multicolumn{2}{c}{ Model Summary } & R & R Square & $\begin{array}{c}\text { Adjusted R Square } \\
\text { Model }\end{array}$ \\
$\begin{array}{l}\text { Std. Error of the } \\
\text { Estimate } \\
1\end{array}$ & $.928^{\mathrm{a}}$ & .862 & .856 \\
\hline a. Predictors: (Constant), Asset allocation, Market timing method, & & &
\end{tabular}

Anova Table 4.6 shows the statistical significance of the model. From the table, the model is statistically significant since $\mathrm{p}<.05$ (Sig. $=.001)$. This means that there is positive relationship between the dependent variable (Shareholders wealth for the companies listed in NSE) and the independent variables (Asset allocation, Market timing method).

Table 4.10: Anova Table of dependent variables (Shareholders wealth for the companies listed in NSE) and independent variables

\begin{tabular}{|c|c|c|c|c|c|c|}
\hline \multicolumn{7}{|c|}{ ANOVA } \\
\hline Model & & Sum of Squares & Df & Mean Square & $\mathbf{F}$ & Sig. \\
\hline \multirow{3}{*}{1} & Regression & 1100.000 & 1 & 1100.000 & 13.220 & $.001^{\mathrm{b}}$ \\
\hline & Residual & 3245.122 & 39 & 83.208 & & \\
\hline & Total & 4345.122 & 40 & & & \\
\hline
\end{tabular}

a. Dependent Variable: Shareholders wealth for the companies listed in NSE

b. Predictors: (Constant), Asset allocation and Market timing investment method

\section{Summary, Conclusions And Recommendations}

This chapter presents a summary of the findings, discussion, conclusions and recommendations for practice and further research on the problem. The general objective of this study was to establish the effect of investments appraisal methods on the shareholders wealth in Nairobi Securities Exchange. wealth for NSC

The study also sought to determine the effects of asset allocations and market timing on shareholders

\section{Summary}

Asset allocation and investment appraisal methods

The study sought to find out whether the companies undertook an investment in bonds as an asset allocation method in order to build shareholders wealth. The study established that investment appraisal methods was affecting the asset allocation findings as presented in Figure 4. From the figure, a majority (88.2\%) of the respondents said that their companies undertook investments in bonds as an asset allocation investment method, while only $11.8 \%$ said that their companies did not.

The study also sought to establish the effects that asset allocation investment methods had on shareholders wealth. The findings were summarized in Table 2 . The table shows that $80.4 \%$ of the respondents said that InvestmentinStocks increases shareholders wealth while $19.6 \%$ said it decreases. $90.2 \%$ said OffshoreInvestments increases shareholders wealth while $9.8 \%$ said it decreases. $60.8 \%$ said InvestmentinamodernPortfolio increases shareholders wealth while $39.2 \%$ said it decreases. $54.9 \%$ said InvestmentinBonds increases shareholders wealth while $45.1 \%$ said it decreases.

\section{MarketTimingMethodon Shareholders Wealth}

The research sought to find out theeffectofmarkettimingmethodonshareholderswealthforthecompanieslistedintheNairobiSecuritiesExchange. The findings were summarized and discussed under this section The study sought to find out if the companies undertake market timing to build shareholders wealth.

The findings of the study were summarised in Figure 4.4. From the figure, $72.5 \%$ of the respondents said that their companies undertakes market timing to build shareholders wealth while $27.5 \%$ of the respondents said that their companies do not.

The research sought to establish the effect that market timing had on shareholders wealth. The findings were summarized in Table 4. From the findings, $45.1 \%$ of the respondents agreed that there had beenapositiverelationshipbetweenmarkettimingandshareholderswealthinthelastfiveyears.
A majority
$(51.0 \%)$ disagreed
that
there had beenanegativerelationshipbetweenmarkettimingandshareholderswealthforthe last fiveyears, $51.0 \%$ strongly agreed that markettiminginvestmentmethod had hadaneffectonshareholderswealthinNSE. 


\section{Conclusions}

There has been a positive relationship between investment in stock and shareholders wealth in the last five years, in addition there has been a negative relationship between investment in stock and shareholders wealth for the last five years offshore investments has had an effect on shareholders wealth in Nairobi Securities Exchange.

There has been a positive relationship between market timing in stock and shareholders wealth in the last five years, furthermore, there has been a negative relationship between market timing and shareholders wealth for the last five years market timing investments methods has had an effect on shareholders wealth in Nairobi securities exchange.

The findings of the study as discussed From Table 4.9, 86.2\% $(\mathrm{R}$ Square $=.862)$ of Shareholders wealth for the companies listed in NSEcould be explained by the independent variables Asset allocation, Market timing method, when other factors were kept constant. It was further discussed in Table.6.which showed the statistical significance of the regression model which was significance for testing the correlation analysis of the variables this means there is a positive relationship between the dependent and the independent variables since $\mathrm{p}<.05$ (Sig. $=.001)$. This also meant that the methods used should be rejected and instead the alternative appraisal methods sought.

\section{Recommendations}

The study established that asset allocation as investment appraisal methods affects positively shareholders wealth for companies listed in Nairobi Securities Exchange. The study therefore recommends that companies should employ the asset allocation as an investment appraisal method.

The study established that Companies listed in Nairobi Securities Exchange should use Market timing as a strategy of buy or sell decisions of financial assets as this would increase returns by predicting future market price.

\section{Suggestion for Further Research}

This study sought to establish the effects of investment appraisal methods on shareholders wealth for firms listed in Nairobi Securities Exchange, the finding of the study cannot be conclusively generalized to other financial institutions in Kenya without considering other factors especially the ones not listed at the investment appraisal methods.

Moreover, this study recommends that further studies be conducted on the effects of profitability of appraisal methods on shareholders wealth in Kenya since this study covered investment appraisal method.

This study was done only on all companies operating in the quoted securities exchange in Nairobi Security Exchange as at $31^{\text {st }}$ Dec. 2013. There should be a study replicated in other sectors of the companies not listed in the Nairobi Securities Exchange and also similar research can be done for other stock exchange in other countries.

\section{References}

[1]. Babbie, E.R. (1990). Survey Research Methods. 2nd edition. Wadsworh Publishing Company.

[2]. Bailey, C.A. (1996). A guide to field research. Thousand Oaks, CA: Pine Forge.

[3]. Chen, H. (1996). "Direction, magnitude and implications of nonresponse bias in mail surveys," Journal of the Marketing Research Society, 38(3), pp 267-276.

[4]. Cooper,G., \& Schindler, J. (2011).Business Research Methods. India: McGraw-hill.

[5]. Al Ehrdba,r (1998). $3^{\text {rd }}$ edn.Eva; The Real Key to Creating Wealth Stern Stewart'sJohn Wisley \& Son New York, USA

[6]. Argyrols,Chris,andRobertKaplan.(1994).Implementingnewknowledge:Thecaseofactivity-

basedcosting. AccountingHorizons(September):83-105.

[7]. Armitage,Howard,andVijayJog.1996.Economicvaluecreation:Whateverymanagementaccountantshouldknow.CMAmagazine(Octob er):21-24.

[8]. Balkom,John,andRogerBrossy.Gettingexecutivestocreatevalue:AcautionarytaleaboutEVA.Chicago,IL:SibsonandCompany,Inc.Inter naldocument.

[9]. BasedManagement:MovingfromAnalysistoAction.Montvale,NJ:InstituteofManagementAccountants.

[10]. Bernard,VictorL.1995.TheFeltham-Ohlsonframework:implicationsforempiricists.ContemporaryAccountingResearch(spring).

[11]. Boguist, J., Milbourn T. and Thakor, A. (1997).The Value Sphere: the Corporate Executivesae. The World Scientific Publishing Company Pte. Ltd. USA.

[12]. Buzzell,Robert,andBradleyT.Gale.1996.ThePIMSPrinciple.NewYork,NY:TheFreePress.

[13]. Cooper, R. D \&Schindlers, P.S (2003).Business Research Methods ( $8^{\text {th }}$ Edn.) New Delhi: Tata McGraw-Hill Edition.

[14]. Cooper,R.,R.Kaplan,L.Maisel,E.Morrissey,andR.Oehm.1994.ImplementingActivity.

[15]. Christine D. Reid (2007) $2^{\text {nd }}$ edn.Encyclopadia of Business and finance. Emerald Group publishing limited Glasgow, UK.

[16]. Copeland,T.,TimK.,\&Jack,M.(1996).Valuation,2nded.NewYork,NY:JohnWiley\&SonsInc.

[17]. David, H.(2004). A Guide to the project management body of knowledge published by project management institute, Philadelphia, USA, $3^{\text {rd }} \mathrm{Edn}$.

[18]. Dixit,A.K.,\&Pindyck, R.S. (1994).Investmentunderuncertainty.Princeton,NJ:PrincetonUniversityPress.

[19]. Duck,J.(1993).Managingchange:Theartofbalancing.HarvardBusinessReview(NovemberDecember):109_

118.ExecutiveCompensationReports.1992.Vol.12,8(August25). 
[20]. Feltham,G.,\&Ohio,

J.(1995).Valuationandcleansurplusaccountingforoperatingandfinancialactivities.ContemporaryAccountingResearchVol.11,2(spring) $: 689-731$.

[21]. Frankel,R

\&Lee,

C.M.C.(1996).AccountingValuation,MarketExpectations,andtheBook-toMarketEffect.Workingpaper,SchoolofBusinessAdministration,UniversityofMichigan.(January).

[22]. Glossary, T. (1999).The Glossary of Book Trade, Publishers Association No.1 Kingsway, London VC2B6XF, England.

[23]. Hagendorff, J., Collins, M., \&Kaesey, K. (2007). Bank deregulations and acquisition activity: the case of the US, Italy and Germany, journal of financial regulations and compliance 15(2),pp199- 205.

[24]. IbbotsonandAssociates.Stock,Bonds,BillsandInflation.Chicago,IL:Yearbooks.InstituteofManagement Accountants.1986.

[25]. Kothari, C. (2004). Research Methodology \& techniques. $2^{\text {nd }}$ ed. NewageInternational publishers, New Delhi, India.

[26]. Michael,L.B. (2006). "BeyondDichotomy:TheCurvilinearRelationshipbetweenSocialResponsibility\&FinancialPerformance," StrategicManagementJournal:1101-1122.

[27]. Mugenda, O., \& Mugenda, A.G. (2003).Research Methods: Quantitative and qualitative approaches.Nairobi: Acts Press.

[28]. Mugenda, O. \& Mugenda A. (2005).Research Method Simplifying City Nairobi; applied Research and Training Services Press.

[29]. Peterson, S. (2012). Investment Theory and Risk Management.ISBN : 978-1-118-12959-3. Germany.

[30]. Richard, A. et al (2011). Qualitative Method of Investment Analysis.Baltimore MD City: United Press Inc. Virginia.

[31]. Ryan P. and G. Ryan (2002)Capital Budgeting Practices of the Fortune 1000: How have Things Changed ? "Journal of Business and Management. 8(4) 355-364 